$\mathrm{V}, \mathrm{KK} 323(470+571)$

ББК 66.3(2Poc)

DOI 10.22394/1682-2358-2019-4-99-106

I.V. Suslov, Candidate of Sciences (Sociology), Docent of the History, Politics and Sociology Department, Saratov State Academy of Law

A.A. Makovsky, Candidate of Sciences (Politics), Senior Lecturer of the History, Politics and Sociology Department, Saratov State Academy of Law

\section{CURRENT TRENDS IN RELIGIOUS SECURITY RESEARCH IN THE LOWER VOLGA REGION}

The analysis of the results of modern scientific research in the field of fixing social and political risks and threats to national security related to the religious factor in the political process in the Lower Volga Region is presented. The authors determine the main trends in studying the specificity of ensuring religious security in Russian regions.

Key words and word-combinations: national security, religious security, threats to national security, state-confessional relations.
И.В. Суслов, кандидат сочиологичских наук, доиент кафедри истории, политологи и сочиологии Саратовской государственной юридической академии (email: suslov85@inbox.ru)

А.А. Маковский, кандидат политических наук, стариий преподаљатель кафедрьг истории, политологии и сочиологи Саратовской государстьенной юридической академии (етаil: aamakovsky@mail.ru)

\section{COBPEMEHНЫЕ ТЕНАЕНЦИИ В ОБААСТИ ИССАЕАОВАНИЯ РЕАИГИОЗНОЙ БЕЗОПАСНОСТИ В НИЖЖНЕМ ПОВОАЖЬЕЕ}

Аннотация. Представлен анализ результатов современных научных исследований в области фиксации реальных общественно-политических рисков и угроз национальной безопасности, связанных с религиозным фактором в политическом процессе Нижнего Поволжья. Определены основные тенденции изучения специфики обеспечения религиозной безопасности в российских регионах.

Ключевые слова и словосочетания: национальная безопасность, религиозная безопасность, угрозы национальной безопасности, государственно-конфессиональные отношения.

$$
\prod_{\text {o }}
$$
-

* Исследование выполнено при подаержке РФФИ в рамках научного проекта № 19-011-00389 «Религиозная безопасность в Нижнем Поволжье: современное состояние и технологии стабилизации». 
чения суверенитета Российского государства актуализировали научный интерес к проблемам религиозной безопасности. Традиџионно в отечественной научной $и$ тературе религиозная безопасность рассматривается в рамках проблемы обеспечения национальной безопасности, государственно-конфессиональных отношений, духовной безопасности и раскрывается как некое состояние защищенности кичности, общества и государства от внутренних и внешних угроз, возникающих в религиозной сфере, необходимое для стабильного конституционного развития Российской Федерации [1, с. 49]. Отметим, что угрозы религиозной безопасности России представмяют собой цемый компмекс условий и факторов нарушения конституџионных прав человека и гражданина, суверенитета и территориальной целостности России. Безусловно, Аанные угрозы носят общенаџиональный характер, при этом в каждом регионе Российской Федерации они дополняются и конкретизируются с учетом внутренней специфики.

Особый интерес вызывает религиозная и наџиональная ситуация в Нижнем Поволжье - регионе, прилегающим к нижнему течению Волги, объединяющему Астраханскую, Волгоградскую и Саратовскую области и Республику Каммыкия. Нижнее Поволжье представмяет собой религиозный центр Евразии, объединяя в себе не только православную и исламскую культуры, но также будАизм, иудаизм, католицизм, протестантизм (проникновение которого связано с историей немцев Поволжья). По своему геополитическому значению Нижнее Поволжье является «буферной» зоной межку Российской Федерацией и Средней Азией, так как весь миграционный экономический транзит к центру России пролегает через приграничные территории данного региона.

В данной статье ставится задача анализа и систематизаџии угроз религиозной безопасности, представленных в научных трудах авторов астраханской, волгоградской и саратовской научных школ, а также опредемения основных тенденџий изучения спеџифики обеспечения религиозной безопасности в указанных регионах.

Исходя из анализа научного массива, следует отметить, что наиболее острой религиозной угрозой для Нижнего Поволжья является радикальные религиозные проявления (в частности ваххабизм) и различные транснациональные террористические организации [2; 3]. В экспертных докмадах Этнологического мониторинга, поАготовменных Институтом этнологии и антропологии РАН [4, с. 79], отмечалось распространение ваххабитской активности в большом количестве районов Астраханской, Волгоградской, Саратовской областей. По мнению астраханского исследователя А.В. Сызранова, основным фактором конфессионацьного риска явцяется бцизость субъектов к радикальному исламскому миру Северного Кавказа и Прикаспия, способствующая активизации миграционных потоков представитемей мусульманских конфессий [5, с. 19].

Проблема радикализаџии религии тесно связана с культурно-конфессиональной идентичностью и религиозными конфликтами. РяА таких авторов, как Е.М. Мирошникова и О.И. Сгибнева [6, с. 62], И.А. Аорошин [7, с. 93], В.В. Штонда [8, с. 171] , В.С. Арягалов, М.С. Топчиев [9, с. 61] , В.С. Слобожникова [10, с. 165] отмечают угрозы и риски, которые скрыты в размывании культурно-религиозного мандшафта России, сопровождающемся потерей ре- 
мигиозных традиций ее народов в связи с ускоряющейся глобализащией. Отказ от традиционных дмя России рекигий в пользу Аеструктивных происходит под влиянием активного прозелетизма агентов транснационацьных рекигиозных организаций. М.А. Аипчанская [11, с. 4] выдемяет прозелитизм как угрозу не только Аля кичности, но и Аля общественной безопасности в цемом. А.П. Романова и М.С. Топчиев [12, с. 169], И.А. Голиков [13, с. 52] , А.В. Кузьмин [14, с. 149] также подчеркивают деструктивную направленность деятельности нетрадиционных Аля российского общества религиозных объединений отечественного и зарубежного происхождения.

Таким образом, проблема культурной мозаичности обретает на российской почве Нижнего Поволжья новое оформление. Распространение радикального ислама, а также различных деструктивных христианских учений, восточных эзотерических практик и новых религиозных движкений (преимущественно западного происхождения) нередко в форме тоталитарных сект рассматривается экспертным сообществом как проявление топоса «детерриториализации религии» [15, с. 56] и в качестве угроз Аля российской цивилизации (и ее традиционных религий как Ауховной основы).

В каждом регионе Нижнего Поволжья существует своя специфика видения религиозной безопасности, угроз и механизмов обеспечения. В астраханской научной школе в вопросе исслеАования религиозной безопасности особый интерес представляют работы М.С. Топчиева. Исследователь отмечает следующие негативные факторы формирования системы конфессионацьной безопасности: отсутствие четкой конџепции общегосударственной конфессиональной политики и разработанного законодательства, отсутствие постоянно ведушегося межконфессионального диалога на федеральном уровне, спонтанный характер взаимоотношений государства и религиозных организаџий, связанный с сиюминутными потребностями политических мидеров воспользоваться религиозным фактором Аля достижения целей, конкуренџия духовных управлений мусульман.

Из позитивных факторов формирования системы религиозной безопасности М.С. Топчиев указывает следующее: благожкелательное отношение к поликонфессиональности на уровне как государства, так и региона, учет руководством области современной геополитической ситуации и фактора внешнего воздействия, внимание федерацьного центра к Астраханскому региону. Основные риски рекигиозной безопасности Астраханской области М.С. Топчиев определяет следующим образом:

1. Миграционные потоки из исламских регионов, обладающие риском распространения радикального ислама и ростом межконфессиональных конфмиктов на бытовой почве.

2. Транснациональные религиозные сети, особенно исламистского характера.

3. Гражданско-правовые и хозяйственные споры, освещающиеся в СМИ как ремигиозные конфмикты.

4. Акты разжигания межконфессиональной вражды, рекигиозного вандамизма и хумиганства [16, с. 99].

В Астраханской области в 2017 г. проводился экспертный опрос по вопросам религиозной безопасности. По мнению экспертов, самым распространенным видом религиозного экстремизма в Астрахани явцяется интраконфессионацьный 
(внутриконфессиональный) (49\% экспертов), на втором месте - экстраконфессиональный (межрелигиозный) (30\% экспертов). Остальные типы религиозного экстремизма (кичностно-ориентированный, этнорелигиозный, религиозно-политический, соџиальный) не актуальны [17, с. 101]. Таким образом, угрозой дмя религиозной безопасности выступают внутренние споры межАу разАичными ответвлениями в христианстве или исламе. Следовательно, основная опасность исходит от глобальных религиозных сетей [18, с. 54], которые в первую очередь способствуют распространению нетрадиционных Аля России христианских, мусульманских, буддистских и околорелигиозных культов.

К негативным факторам религиозной дестабилизации относится распространение деструктивных транснациональных новых религий с помощью интернет-ресурсов. При этом исследователи указывают, что историческая поликонфессиональность региона явмяется благоприятным ресурсом Аля поАдержания толерантности к религиозной инаковости. Повышение культурной гетерогенности в публичном пространстве, распространение, например, моды среди девушек-мусульманок на ношение хиджаба не воспринимается преАставителями остальных конфессий как угроза [8, с. 172].

В волгоградской политологической школе С.А. Панкратовым и Е.М. Ариновой поАробно исслеАуется проблема полититизации религии в XXI в., которая создает определенные общественно-политические риски национальной безопасности [19]. Е.М. Аринова выдемяет угрозы для развития идей миберализма в исламской среде [20]. Политизация ислама нередко выражается в появлении различных религиозно-политических доктрин, отриџающих демократические ценности. Соотношение демократических, миберальных ценностей и традиционного ислама - это тот фактор, от которого зависит возможность взаимодействия традиционных исламских организаций и органов государственной власти. Например, теория «исламского пути развития» Аекларирует стремление к миру, соџиальной справедливости, Аемократии, равноправию всех народов и наџий, что противоречит идейным основаниям радикального «ваххабизма», который многими воспринимается как основной источник проблем. Н.В. Пискунов опредемяет диалог культур в контексте этноконфессионального кроссинга гражданского общества и государства как основной тренА публичной политики в XXI в. [21, с. 205].

В Волгоградской области исследователи отмечают ряд положительных изменений в межконфессиональных отношениях. ОАнако А.Г. Нестерова указывает на негативные тенденџии, наметившиеся в религиозной ситуации за последние несколько цет. В первую очередь речь идет о "национализации» религии - возникновении жесткой связи межАу этнической и конфессиональной идентичностью, что опасно усимением националистических настроений. Национализация и внутренняя авторитарность характерны для ислама, православия, а также в той $и$ иной степени и Аля остальных религий и верований России. В то же время в Волгоградском регионе наблюдается рост ксенофобных настроений. Основное раздражение вызывают мигранты, которые в большинстве своем представляют ислам. Всплеск ксенофобии в Волгоградской области был обусловлен рядом террористических актов, осуществленных на территории области исламскими боевиками (2000, 2011 и 2013 гг.) [22]. 
Волгоградские политологи выделяют еще одну новую тенденцию: вербовщики из террористической организации «Исламское государство» все чаще завлекают молодых граждан славянской наџиональности. Е.В. Ефанова и Е.М. Аринова, изучив распространение исламского радикализма в молодежной среде, отметили девальвацию традиционных ценностей, деидеологизацию массового сознания, правовой нигилизм среди молодежного сообщества, создание соџиально-политического дисбаланса в результате иммиграции. В качестве факторов радикализации молодежи называются: делегитимаџия власти, дестабилизаџия внутриполитической обстановки в стране, разжигание ксенофобии и религиозной нетерпимости, отсутствие системы соџиальных гарантий и чувство незащищенности [23, с. 249].

И.В. Барышникова, Е.О. Беликова, А.Г. Нестерова провели соџиологическое исследование и отметили необходимость повышения уровня религиовеАческой подготовки специалистов, работающих в области государственно-религиозных отношений и юридической подготовки офиџиальных преАставителей различных религиозных организаций. В докладе указано, что большинство респондентов черпает информаџию о религиозных организаџиях и о религиях из СМИ, что формирует искаженные представления у населения о религиозной ситуации в стране и регионе [24, с. 139].

Цейтмотивом иссмедований волгоградской научной школы явмяется проблема политизации религии. При этом особое внимание удемяется общественно-политическим рискам, связанным с молодежью, так как основные угрозы исходят от потери религиозной идентичности молодых гражАан и их радикализации. Механизмы гармонизации молодого поколения представлены в работе Р.М. Петруневой, В.А. Васильевой, Н.В. Аулиной [25], раскрывающих опыт по формированию гражданской идентичности в высшем учебном заведении.

Особое внимание проблемам религиозных угроз уделяется в саратовской научной школе политической регионалистики. В.С. САобожникова опреАемяет религиозную безопасность как составной эмемент наџиональной безопасности, описывает институџиональный потенџиал разрешения религиозных противоречий в Саратовской области и анализирует деятельность власти и реакщию общества, связанные с трансформацией государственно-конфессиональных отношений. Исследователь констатирует формирование в Российской Федераџии особого понимания светскости, подразумевающей тесные партнерские отношения межАу государством и конфессиями.

В.С. Слобожникова вводит понятие «религиозный ресурс государства» [10, c. 165] и отмечает, что попытка государства Аостичь с помощью религиозных групп определенных политических целей может повлечь за собой негативную реакщию со стороны общества и конфессий, дестабилизировать обстановку и внести угрозу религиозной безопасности. Серьезная угроза Амя религиозной безопасности видится в активной миссионерской деятельности нетрадиџионных Амя России религий и усияении миграционных потоков (особенно из СреАней Азии), которые несут в себе угрозу религиозной безопасности [26, с. 192; 27; 28].

Представитель саратовской школы А.А. Маковский среди религиозных угроз национальной безопасности выдемяет конкуренцию религиозных организаций межАу собой, властную дифференциацию ремигиозных организаций. Предупреж- 
дение социальной напряженности, по мнению исследователя, видится в развитии механизмов политического управления на нормативном, информационно-коммуникативном и политическом уровнях. Аیя минимизации конфликтных ситуаций обеспечения религиозной безопасности важно законодательно закрепить основы вероисповедной политики, организовать открытые обсуждения государственноконфессиональных практик, осуществить переход от еАиничных проектов социально-политического партнерства к системному сотрудничеству [29, с. 226] .

В Аиссертационном исследовании М.А. Пегашевой преАставлен сравнительный анализ взаимодействия органов государственной власти и религиозных организаций по вопросам гармонизации населения в Астраханской, Волгоградской и Саратовской области [30]. В работах саратовских исследователей О.А. Аиџенбергер, Н.В. Семенова проанацизирована динамика изменения этноконфессиональной структуры населения, выявлены ключевые причины возникновения конфликтов в Аанной сфере, определены основные направления их политического регулирования и предупреждения [31; 32, с. 144] .

Работы ученых доказывают факт особой угрозы от деятельности нетрадиционных Аля российского общества религиозных объединений Аеструктивной направменности, чей прозелитизм представцяет собой навязчивое стремление обратить Аругих в свою веру. Проџесс глобализации и вестернизации актуализирует угрозу потери религиозных традиций народов России, духовных скреп [13, с. 49].

В научных кругах существует мнение о необходимость принятия закона о запрете прозелитизма. При этом особенностью саратовской ситуации является активная деятельность неоязыческих организаций, которые И.А. Голиков сравнивает с исламскими радикалами [13, с. 49]. Например, «Misanthropic Division» выступающее за установление мирового господства «белой расы», как и исламские экстремисты, не имеет еАиного командования и преАставцяет собой сеть автономных ячеек, ведущих работу на территории нескольких государств. И исмамские радикалы, и славянские язычники разделяют идеи воинствующего антиамериканизма, одобряют силовые методы борьбы с соџиальной несправедливостью, а главным инструментом рекрутинга выступает соблазнение молодых Аюдей возможностью поучаствовать в реализаџии некой высокой идеи, и исламисты и неоязычники рассматривают христианство как врага (причем слабого).

Таким образом, в саратовской научной школе религиозная безопасность рассматривается как элемент государственно-конфессиональных отношений, в которых существуют деструктивные, нейтральные и партнерские религиозные организации по отношению к органам вцасти, а также как элемент национацьной безопасности, которую необходимо постоянно совершенствовать через нормативно-правовую базу.

Анализ современного научного массива в области исследования религиозной безопасности в Нижнем Поволжье позволиц выявить несколько тенденций. Во-первых, религиозная безопасность в научной митературе рассматривается с точки зрения национальной, духовной безопасности, государственно-конфессиональных отношений, правового обеспечения прав свобод совести и вероисповедания [33; 34]. Во-вторых, исследователи выделяют общероссийские угрозы национальной безопасности: религиозный экстремизм, прозелитизм, 
потерю религиозной идентичности и религиозной культуры, деятельность деструктивных религиозных групп. В-третьих, в Нижнем Поволжье существует региональная специфика религиозных рисков. Это прежде всего «примитивное» понимание принџипа светскости со стороны СМИ, граждан, истебцишмента, радикализация молодежки, миграционные риски, смена наџионального и конфессионального портрета региона, недостаток квалифицированных каАров, разобщенность религиозных мидеров. В-четвертых, несмотря на наличие большого количества работ, предложенные механизмы обеспечения религиозной безопасности размыты и сводятся к силовым методам и правотворчеству. При этом недостаточное, на наш взгляА, внимание уделено пробцемам «религиозных войн» на примере Шри-Аанке и Новой Зеландии, а также выявлению роли религиозного фактора в цветных революциях.

\section{Библиографический список}

1. Тарасевич И.А. Конституционно-правовые основы религиозной безопасности Российской Федерации: дис. ... д-ра юрид. наук. Тюмень, 2015.

2. Лепехин A.A. Религиозно-политический экстремизм и радикализм: понятие и истоки возникновения в прикаспийском регионе // Право и глобальный социум. 2016. № 1. С. 54-59.

3. Панкратов С.А., Редькина О.Ю. Этноконфессиональные факторы обеспечения стабильного и безопасного развития Волгоградской области // Политическое регулирование региональных этноконфессиональных отношений: особенности, новации, перспективы / отв. ред. А.А. Вилков. Саратов, 2016. С. 145-151.

4. Межэтнические и конфессиональные отношения в Приволжском федеральном округе: экспертный доклад / под ред. В.А. Тишкова, В.В. Степанова. М.; Ижевск, 2013. С. 79-86.

5. Сызранов А.B Государственная политика России по борьбе с исламским экстремизмом на территории Поволжья в конце XX - начале XXI в. // Каспийский регион: Политика, экономика, культура. 2013. № 2. С. 19-24.

6. Мирошникова Е.М., Сгибнева О.И. Религиозная политика светского государства в условиях религиозного многообразия // LogosetPraxis. 2017. № 3. С. 62-73.

7. Дорошин И.А. Глобальное измерение религиозного протеста в обществе риска // Век глобализации. 2013. № 2. С. 93-100.

8. Топчиев М.C., Штонда В.В. Трансформация отношения к хиджабу как к маркеру чужого в современной культуре // Каспийский регион: политика, экономика, культура. 2017. № 3. С. 171-179.

9. Дрягалов В.C., Топчиев М.C. Религиозная трансгрессия и религиозная идентичность молодежи на фронтирных территориях Северного Прикаспия // Человек. Сообщество. Управление. 2016. Т. 17, № 4. С. 61-82.

10. Слобожникова В.С. Религиозность как политический ресурс Российского государства // Политическая наука. 2013. № 2. С. 165-176.

11. Липчанская M.A. Светское государство в современной России как фактор обеспечения национальной безопасности // Вестник Поволжского института управления. 2016. № 1. С. 4-9.

12. Романова А.П., Топчиев М.С. Конфессиональная политика и религиозные сети в современной России (на примере поликультурного региона - Астраханская область) // Сети в публичной политике. М., 2014. С. 169-176.

13. Голиков И.А. Классификация славянских неоязыческих культов: проблемы идентификации в сети Интернет // Религиозные общности в сетевых структурах социального порядка: протестная динамика и институциональная устойчивость российского региона / под ред. Д.А. Ченцовой. Саратов, 2018. С. 52-64.

14. Кузьмин А.В. Феномен деструктивности новых религиозных движений: дис. ... канд. филос. наук. Белгород, 2009. 
15. Дринова E.M. Национальная модель политической модернизации России и топосы политизации религии // Власть. 2014. № 11. С. 56-61.

16. Топчиев М.C. Специфика государственной политики регулирования конфессиональных отношений в полиэтничном регионе (на примере Астраханской области) // Каспийский регион: политика, экономика, культура. 2013. № 1. С. 99-106.

17. Бочарникова И.С., Постнов С.Д. Роль традиционных религий в противодействии религиозному экстремизму: региональный аспект // Каспийский регион: политика, экономика, культура. 2017. № 1. С. 101-107.

18. Дринова Е.М., Панкратов С.А. Политизация института религии в условиях модернизации российского общества и государства // Наука Красноярья. 2016. № 5.

19. Панкратов С.А., Дринова Е.М. Многообразие моделей модернизации и политизации религии: теоретические и практические аспекты // Право и политика. 2015. № 1 (181). С. 19-24.

20. Дринова E.M. Политическая модернизация и исламские партии: тернистый путь к нелиберальной демократии // Исламоведение. 2014. № 1.

21. Дринова Е.М., Пискунов Н.В. Диалог культур в пространстве публичной политики // СОЦИОСФЕРА. 2017. № 4. С. 205-208.

22. Нестерова А.Г. Динамика религиозной ситуации в Волгоградской области (2011-2014 гг.) // Научный результат. URL: https://religious.life/2017/02/nesterova-dinamika-religioznoj-situacii-vvolgogradskoj-oblasti-2011-2014/

23. Ефанова Е.В., Дринова Е.M. К вопросу о распространении исламского радикализма в молодежной среде в современной России (на примере субъектов ЮФО) // Теории и проблемы политических исследований. 2016. Т. 5, № 5А. С. 249-257.

24. Барышникова И.В., Беликова Е.О., Нестерова А.Г. Религиозная ситуация в Волгоградской области // Вестник ВолГУ. Сер.: 9. 2009. № 7.

25. Петрунева Р.М., Васильева В.Д., Дулина Н.В. Опыт Волгоградского опорного университета в развитии межнационального и межконфессионального взаимодействия в регионе // Вестник Сургутского государственного педагогического университета. 2018. № 1. С. 161-167.

26. Слобожникова В.C. Религиозная безопасность современной России в контексте международных миграционных процессов // Государство, общество и Церковь: миграция и межкультурное многообразие: материалы науч.-практ. конф. с международным участием, г. Новосибирск, 29-30 мая 2018 г.: в 2 ч. / под ред. Л.В. Савинова. Новосибирск, 2018. Ч. 1. С. 192-196.

27. Слобожникова В.С. Официальная власть о религии и политике в современной России (2012-2014 гг.) // Четверть века политической науки в российской провинции: сборник научных трудов. Саратов, 2015. С. 55-60.

28. Слобожникова В.С. Корректировка государственно-конфессиональных отношений в 2016 году // Вестник Саратовской государственной юридической академии. 2016. № 6. С. 197-203.

29. Маковский A.A. Конфликтогенный потенциал государственно-конфессиональных взаимодействий в региональном политическом пространстве // Время больших перемен: политика и политики: материалы Всерос. науч. конф. РАПН (Москва, РУДН, 24-25 ноября 2017 г.) / под ред. О.В. Гаман-Голутвиной. М., 2017. С. 226-228.

30. Пегашева М.A. Взаимодействие органов государственной власти и институтов гражданского общества в сфере этноконфессиональных отношений: дис. ... канд. полит. наук. Саратов, 2011.

31. Лиценбергер О.А. Миграция и этнические стереотипы (по материалам социологического исследования в Саратовской области) // Вестник ПАГС. 2014. № 7. С. 69-74.

32. Лиценбергер О.А., Семенов Н.В. Этноконфессиональная ситуация в региональном политическом пространстве, экспертная оџенка (Саратовская обцасть) // Вестник российской нации. 2009. № 5. С. 144-161.

33. Топчиев М.С. Религиозные сети в контексте культурной безопасности Юга России // Каспийский регион: политика, экономика, культура 2016. № 4. С. 111-117.

34. Беликова E.O. Поиски стратегии социологического изучения религиозной идентичности // Мониторинг общественного мнения. 2018. № 2 (144). С. 116-127. 